Marjan Sternad - Tomas Skrucany - Borut Jereb*

\title{
INTERNATIONAL LOGISTICS PERFORMANCE BASED ON THE DEA ANALYSIS
}

Logistics is a very important service, which can influence the international trade. However, the rates in the development of international activities vary by country. In developing countries, the share of the logistics services is increasing, while the share of manufacturing activities, especially those with the lower added value, is declining due to the relocation of production to other countries. In order to achieve competitive advantages in the logistics sector, the development of logistics services with the higher added value is required. The effectiveness of logistics processes is very important for international competitiveness. In the paper, is presented the literature review on logistics performance. After presenting relevant research, the effectiveness of logistics is compared using the logistics performance index based on the Data Envelopment Analysis (DEA). The DEA analysis is a benchmarking technique which is useful for a multi-criteria comparison. Values of the international logistics performance index for 2016, for selected European countries, were used for the input and output variables of the DEA model. European countries rank high in the international comparison of the logistics performance index. In the paper, it was found out that the compared countries are competitive in international business, but not all the countries are considered as efficient. Germany achieves the highest points in the international comparison of the LPI but, does not achieve efficiency. We also found out that Austria, Serbia, Russian Federation and Bosnia and Herzegovina were efficient, while other compared countries did not.

Keywords: international logistics performance, logistics performance index, DEA analyses, logistics efficiency

\section{Introduction}

In a globalizing economy, countries and companies are competing in the international environment. For an economy such as the Slovenian economy, openness and the ability to integrate into international business are the most important factors. By participating in markets, the country becomes well known and improves its international position. Competition in the international trade has become one of the very important factors of the state economy, which is reflected in the export efficiency and import profile [1].

Different authors suggest the primary forms of measurement for capturing the performance of transformational processes [2], [3], [4]:

- utilization (spending metrics, financial and nonfinancial performance, inventory measures),

- productivity (total factor productivity and financial productivity measures),

- effectiveness (quality of the process output by comparing the actual output to the standards).

The effectiveness of logistics processes is very important for international competitiveness. Logistics is a part of the supply chain that plans, introduces and manages an efficient storage of goods, services and relevant information from their sources to their use, in order to cater for the requirements of buyers and sellers [5]. The meeting customer needs is one of the most important characteristics of the logistics process. Efficiency of this act is evaluated by the customer satisfaction. Stopka describes different methods [6]. The analysis of movements of goods in space and time has recently become increasingly important. Nowadays, there is an increasing demand for full tracking of the complete physical flow of goods; in other words, monitoring the flow of goods in time and space. New computational technologies and hardware are used for measuring, evaluating and customer information. Kubasakova and Krajcovic studied some of these technologies [7], [8]. According to Gnap, logistics is very important service, which can influence the international trade and the national GDP [9]. However, the rates in the development of international activities vary by country. In developing countries, the share of the logistics services is increasing, while the share of manufacturing activities, especially those with the lower added value, is declining due to the relocation of production to other countries. In order to achieve the competitive advantages in the logistics sector, development of logistics services with the higher added value is required. Javalgi and Martin [10] emphasize the importance of the logistics services in the international economy, as the internationalization of services affects the competitiveness of companies and increases comparative advantages of individual countries. Saez et al. [11] note that services also logistics are a source of diversification of exports of each country. Services with the higher added value, which include logistics services, are at the forefront. Even in a broader view, transport services can often be seen as a primary tool in the improvement of the value chain of traded goods, not only services [1]. Winsted and Patterson [12] warn about legislative restrictions, international competition, knowledge and resource constraints in terms of infrastructure and superstructure when considering exports of services.

\footnotetext{
* ${ }^{1}$ Marjan Sternad, ${ }^{2}$ Tomas Skrucany, ${ }^{1}$ Borut Jereb

${ }^{1}$ Faculty of Logistics, University of Maribor, Slovenia

${ }^{2}$ Faculty of Operation and Economics of Transport and Communications, University of Zilina, Slovakia

E-mail: tomas.skrucany@fpedas.uniza.sk
} 


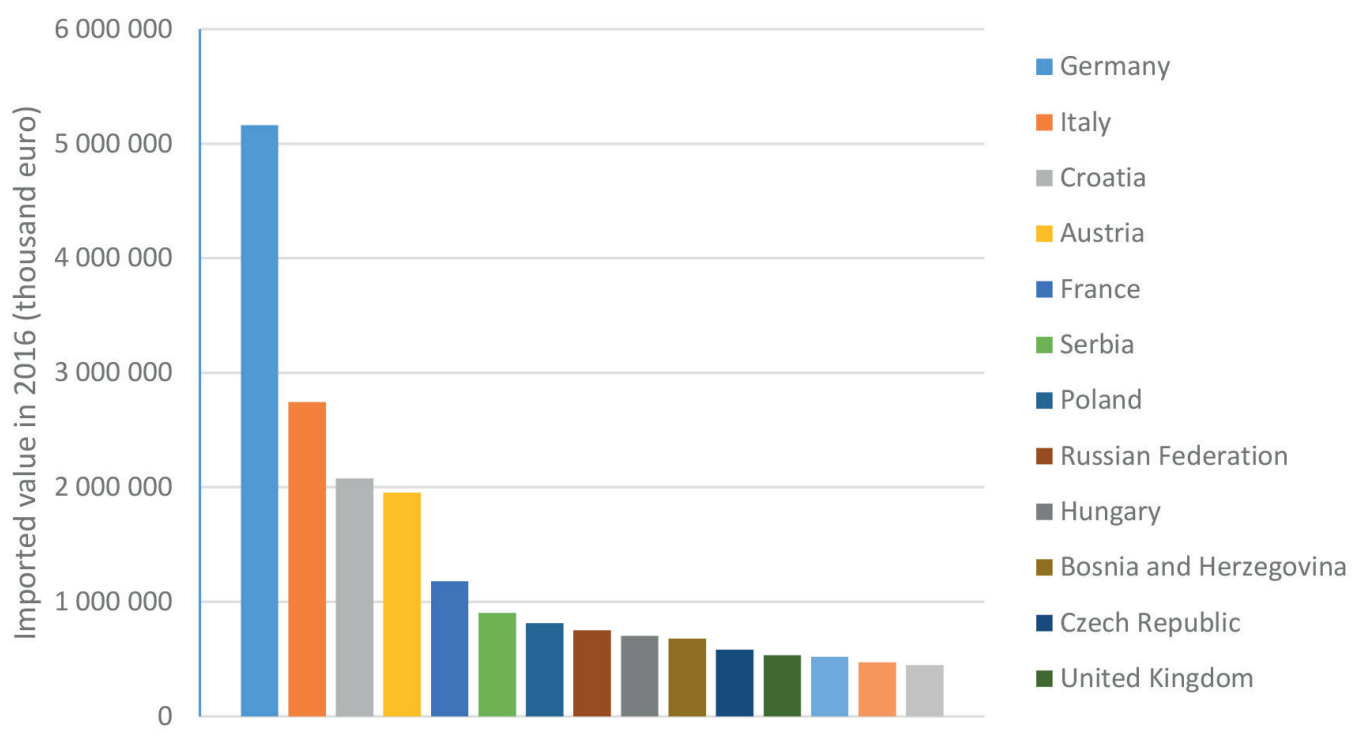

Figure 1 The most important trading partners [1]

Many authors compare the effectiveness of logistics by using different methods. Sternad et al. [13] compare the import and export efficiency of transport services by using a modified RCA (revealed comparative advantages) index, which then focuses only on services and it does not take into account the total exports of each country. They found that Slovenia has achieved a comparative advantage measured by the RCA index. In order to preserve its strength in the transport sector, it will be necessary to increase the added value of transport services along with the services that enhance the value of the transport process in the future.

Hilmola [14] compared the efficiency of transport chains by using a data envelopment analysis (DEA). He found out that the DEA analysis is an appropriate method for analyzing the transport chains. Petrovic et al. [15] used the DEA approach for a cross-country evaluation of rail freight transport. The authors (ibd.) recognized the DEA as a method of great potential for measuring the efficiency of the logistics sector. Marti et al. [16] used the DEA approach to compare logistics performance index for different countries. The authors used the input-oriented DEA efficiency model. They found out that the logistics performance depends largely on the income and geographical area.

Effectiveness of logistics using the logistics performance index based on the DEA analysis is compared in this paper. The logistics performance index (LPI) is a benchmarking tool created to help countries to identify the challenges and opportunities they face in their performance in trade logistics and what they can do to improve their performance [17]. Data for international LPI, which provide qualitative evaluations of the country in six areas by its trading partners, were used in this paper.

The DEA analysis is a benchmarking technique, which is useful for a multi-criteria comparison. For each individual observation with an objective of calculating, the DEA optimizes a discrete piecewise frontier determined by a set of Pareto-efficient decision-making units [18].

Based on the presented issues, the following research question was answered:
RQ: Are the top performer countries based on international LPI also effective?

\section{Methodology}

The international logistics performance by using a Data Envelopment Analysis (DEA), which is a linear mathematical programming approach that evaluates the efficiency of homogeneous decision-making units (DMUs), was analyzed. Efficiency is the ratio between the outputs produced and the number of inputs used. DEA optimizes the performance measure of each DMU [18]. The DMUs that are not on the efficiency frontier are inefficient. An inefficient unit must reach the efficiency frontier in order to become efficient. There are three options to become efficient [19]:

- by reduction of the inputs with constant outputs (inputoriented approach),

- by increasing the outputs with constant inputs (outputoriented approach),

- to increase outputs and reduce the inputs.

Based on characteristics of the DMUs and relevant research [16], the logistics performance is going to be based on a CCR (Charnes, Cooper and Rhodes model) input-oriented model with constant return to scale (CRS). The mathematical programming problem for the CCR input-oriented is [18]:

$$
\begin{aligned}
& \max \frac{\sum_{r} u_{r} y_{r o}}{\sum_{i} v_{i} x_{i o}} \\
& \frac{\sum_{r} u_{r} y_{r j}}{\sum_{i} v_{i} x_{i o}} \leq 1, \text { for } j=0,1, \ldots, n \\
& \frac{u_{r}}{\sum_{i} v_{i} x_{i o}} \geq \varepsilon, \text { for } r=1, \ldots, s \\
& \frac{v_{i}}{\sum_{i} v_{i} x_{i o}} \geq \varepsilon, \text { for } r=1, \ldots, m
\end{aligned}
$$

where:

- $x$ and $y$ are the input and output vectors,

- $\quad v$ and $u$ are the input and output weights. 
Table 1 Descriptive statistics of logistics performance components

\begin{tabular}{|c|c|c|c|c|c|c|c|}
\hline Components & Mean & Median & Max. & Country & Min. & Country & $\begin{array}{l}\text { Standard } \\
\text { Deviation }\end{array}$ \\
\hline \multicolumn{8}{|l|}{ Inputs } \\
\hline $\mathrm{X}_{1}$ Customs & 3.33 & 3.37 & 4.12 & Germany & 2.01 & Russian Federation & 0.61 \\
\hline $\mathrm{X}_{2}$ Infrastructure & 3.50 & 3.42 & 4.44 & Germany & 2.43 & Russian Federation & 0.66 \\
\hline $\mathrm{X}_{3}$ International shipments & 3.37 & 3.54 & 3.94 & Netherlands & 2.28 & Bosnia and Herzegovina & 0.52 \\
\hline \multicolumn{8}{|l|}{ Outputs } \\
\hline $\mathrm{Y}_{1}$ Logistics competence & 3.53 & 3.52 & 4.28 & Germany & 2.52 & Bosnia and Herzegovina & 0.56 \\
\hline $\mathrm{Y}_{2}$ Tracking \& tracing & 3.59 & 3.65 & 4.36 & Austria & 2.56 & Bosnia and Herzegovina & 0.60 \\
\hline $\mathrm{Y}_{3}$ Timeliness & 3.86 & 3.91 & 4.45 & Germany & 2.94 & Bosnia and Herzegovina & 0.49 \\
\hline
\end{tabular}

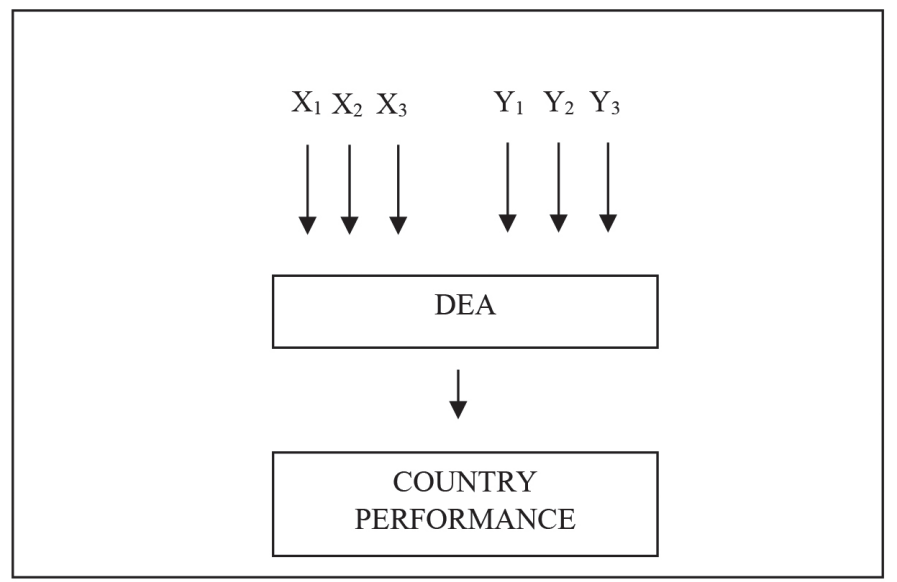

Figure 2 The research model

For the input and output variables of the model, values of the international logistics performance index for 2016 [20] for Slovenia and the ten most important trading partners by the value of import from Slovenia (see Figure 1), were used [1].

The international logistics performance index provides qualitative evaluations of a country in six areas by its trading partners. The six core components are [17]: the efficiency of customs and border clearance, the quality of trade and transport infrastructure, the ease of arranging competitively priced shipments, the competence and quality of logistics services, the ability to track and trace consignments and the frequency with which shipments reach consignees within scheduled or expected delivery times. Table 1 presents the descriptive statistics of logistics performance components.

Data were analysed by using the Open Source DEA software [19]. Figure 2 presents the research model.

\section{Results}

The efficiency of the logistics sector is becoming an increasingly important factor for competitive success in international business [21]. The largest logistics market in the EU is Germany [22]. Slovenia is affiliated with Germany through the international trade, and it is important that Slovenia works more effectively on the logistics market. Slovenia reaches higher LPI than Croatia, Serbia, Russian Federation and Bosnia and Herzegovina, but far behind Germany, Austria and France [17].
Table 2 shows the results of the DEA analysis for the CCR input-oriented model. The ratio between the outputs produced and the number of inputs used presents efficiency. Austria, Serbia, Russian Federation and Bosnia and Herzegovina received score 1 and they are considered as efficient. Other countries are inefficient. Hungary gets the lowest score.

The slacks exist only for those countries, which are identified as inefficient. The slacks present only the leftover portions of inefficiencies and they are needed to push the DMU to the frontier. Table 3 presents the results of slacks for the inefficient countries. Slovenia cannot reduce any inputs but it must augment logistics competence and timeliness. Italy represents the same case. Similarly, Slovakia must augment logistics competence and tracking. Germany and France have the very good quality of trade and transport infrastructure. They can reduce these inputs and they can also augment the timeliness. Hungary must improve the competence and quality of logistics services. Croatia, Poland and Czech Republic can reduce the efficiency of customs and border clearance or augment the timeliness if they want to be efficient.

Efficiency targets for inputs and outputs are presented in Table 4. Targets are the results of respective slack values added to proportional reduction amounts. To calculate the target values for an input, the input value is multiplied with an optimal efficiency score [18]. Projection describes the path of inefficient DMUs towards the efficient frontier. The target values for efficient countries are equivalent to their original input and output values.

Comparison between international LPI and efficiency for compared countries (Table 5) shows that the country which is 
Table 2 Results of CCR input-oriented model solution

\begin{tabular}{|c|c|c|}
\hline DMUs & Value & Efficient \\
\hline Slovenia & 0.950 & \\
\hline Germany & 0.997 & \\
\hline Italy & 0.947 & \\
\hline Croatia & 0.950 & \\
\hline Austria & 1 & Yes \\
\hline France & 0.976 & \\
\hline Serbia & 1 & Yes \\
\hline Poland & 0.951 & \\
\hline Russian Federation & 1 & Yes \\
\hline Hungary & 0.906 & \\
\hline Bosnia and Herzegovina & 1 & Yes \\
\hline Czech Republic & 0.975 & \\
\hline United Kingdom & 0.971 & \\
\hline Unites States of America & 1 & Yes \\
\hline Slovakia & 0.907 & \\
\hline Netherlands & 0.960 & \\
\hline
\end{tabular}

Table 3 Input and output slacks

\begin{tabular}{|c|c|c|c|c|c|c|}
\hline DMUs & Customs & Infrastructure & $\begin{array}{c}\text { International } \\
\text { shipments }\end{array}$ & $\begin{array}{c}\text { Logistics } \\
\text { competence }\end{array}$ & $\begin{array}{l}\text { Tracking \& } \\
\text { tracing }\end{array}$ & Timeliness \\
\hline Slovenia & 0.000 & 0.000 & 0.000 & 0.030 & 0.000 & 0.037 \\
\hline Germany & 0.552 & 0.331 & 0.000 & 0.000 & 0.000 & 0.263 \\
\hline Italy & 0.000 & 0.000 & 0.000 & 0.010 & 0.000 & 0.028 \\
\hline Croatia & 0.384 & 0.000 & 0.050 & 0.000 & 0.000 & 0.293 \\
\hline Austria & 0.000 & 0.000 & 0.000 & 0.000 & 0.000 & 0.000 \\
\hline France & 0.108 & 0.000 & 0.000 & 0.000 & 0.000 & 0.000 \\
\hline Serbia & 0.000 & 0.000 & 0.000 & 0.000 & 0.000 & 0.000 \\
\hline Poland & 0.224 & 0.000 & 0.125 & 0.000 & 0.000 & 0.110 \\
\hline Russian Federation & 0.000 & 0.000 & 0.000 & 0.000 & 0.000 & 0.000 \\
\hline Hungary & 0.000 & 0.000 & 0.000 & 0.114 & 0.000 & 0.000 \\
\hline $\begin{array}{l}\text { Bosnia and } \\
\text { Herzegovina }\end{array}$ & 0.000 & 0.000 & 0.000 & 0.000 & 0.000 & 0.000 \\
\hline Czech Republic & 0.201 & 0.000 & 0.099 & 0.019 & 0.000 & 0.308 \\
\hline United Kingdom & 0.313 & 0.073 & 0.000 & 0.000 & 0.000 & 0.055 \\
\hline $\begin{array}{l}\text { Unites States of } \\
\text { America }\end{array}$ & 0.000 & 0.000 & 0.000 & 0.000 & 0.000 & 0.000 \\
\hline Slovakia & 0.065 & 0.000 & 0.000 & 0.175 & 0.303 & 0.000 \\
\hline Netherlands & 0.537 & 0.146 & 0.000 & 0.000 & 0.000 & 0.270 \\
\hline
\end{tabular}

a top performer in logistics (Germany) is not efficient. Germany has a good quality of trade and transport related infrastructure, but it must improve timeliness in terms of infrastructure quality. European countries with the higher LPI ranking have a similar problem (Netherlands and France).

\section{Conclusion}

Logistics is becoming the most important factor in achieving competitive advantages in international business. Smaller economies than Slovenia depend on competitiveness in the international environment, so they need to improve their processes in international trade. The quality of logistics processes depends on various factors.

In this paper, the effectiveness of logistics processes was analyzed using the DEA analysis, which makes it possible to compare performance across countries. As the input data, were used the logistics performance index for 2016: the efficiency of the clearance process, the quality of trade and transport related infrastructure and assessment of the simplicity of arranging competitive price pricing. Output data of the DEA model are 
Table 4 Projections

\begin{tabular}{|c|c|c|c|c|c|c|}
\hline DMUs & Customs & Infrastructure & International shipments & $\begin{array}{l}\text { Logistics } \\
\text { competence }\end{array}$ & $\begin{array}{l}\text { Tracking \& } \\
\text { tracing }\end{array}$ & Timeliness \\
\hline Slovenia & 2.736 & 3.030 & 2.945 & 3.230 & 3.270 & 3.507 \\
\hline Germany & 3.554 & 4.094 & 3.842 & 4.280 & 4.270 & 4.713 \\
\hline Italy & 3.267 & 3.589 & 3.456 & 3.780 & 3.860 & 4.058 \\
\hline Croatia & 2.532 & 2.840 & 2.913 & 3.210 & 3.160 & 3.683 \\
\hline Austria & 3.790 & 4.080 & 3.850 & 4.180 & 4.360 & 4.370 \\
\hline France & 3.513 & 3.914 & 3.552 & 3.920 & 4.020 & 4.250 \\
\hline Serbia & 2.500 & 2.490 & 2.630 & 2.790 & 2.920 & 3.230 \\
\hline Poland & 2.886 & 3.015 & 3.146 & 3.390 & 3.360 & 3.910 \\
\hline $\begin{array}{l}\text { Russian } \\
\text { Federation }\end{array}$ & 2.010 & 2.430 & 2.450 & 2.760 & 2.620 & 3.150 \\
\hline Hungary & 2.739 & 3.114 & 3.120 & 3.451 & 3.400 & 3.880 \\
\hline $\begin{array}{l}\text { Bosnia and } \\
\text { Herzegovina }\end{array}$ & 2.690 & 2.610 & 2.280 & 2.520 & 2.560 & 2.940 \\
\hline Czech Republic & 3.288 & 3.275 & 3.459 & 3.669 & 3.840 & 4.218 \\
\hline United Kingdom & 3.551 & 4.015 & 3.661 & 4.050 & 4.130 & 4.385 \\
\hline $\begin{array}{l}\text { Unites States of } \\
\text { America }\end{array}$ & 3.750 & 4.150 & 3.650 & 4.010 & 4.200 & 4.250 \\
\hline Slovakia & 2.908 & 2.937 & 3.091 & 3.295 & 3.423 & 3.810 \\
\hline Netherlands & 3.419 & 3.974 & 3.784 & 4.220 & 4.170 & 4.680 \\
\hline
\end{tabular}

Table 5 Comparison between international LPI and efficiency

\begin{tabular}{lcc}
\hline DMUs & Rank International LPI & Efficient \\
\hline Slovenia & 50 & \\
Germany & 1 & \\
Italy & 21 & \\
Croatia & 51 & Yes \\
Austria & 7 & Yes \\
France & 16 & Yes \\
Serbia & 76 & Yes \\
Poland & 33 & \\
Russian Federation & 99 & \\
Hungary & 31 & Yes \\
Bosnia and Herzegovina & 97 & \\
Czech Republic & 26 & \\
United Kingdom & 8 & \\
Unites States of America & 10 & \\
Slovakia & 41 & 4 \\
Netherlands & & \\
\hline
\end{tabular}

competence and quality of logistics services, the ability to track and trace consignments and timeliness. For the comparative analysis, the efficiency of Slovenia was compared to the ten most important trading partners by the value of import from Slovenia.

Within the international comparison, Slovenia is not efficient regarding logistics. Slovenia cannot reduce any inputs but it must augment logistics competence and timeliness.

In this paper, it was also found out that Austria, Serbia, Russian Federation and Bosnia and Herzegovina were efficient, while other compared countries were not. Germany and France are ineffective due to the good quality trade and transport infrastructure, as they need to improve timeliness.

The logistics market is developing rapidly in the European Union. European countries rank high in the international comparison of the logistics performance index. Compared countries are competitive in international business, but not all the countries are considered as efficient. Germany achieves the highest points in the international comparison of the LPI but it does not achieve efficiency, as often high investments in the logistics sector are visible only in a few years. The economy cannot often follow the rapid technological changes in logistics. 


\section{References}

[1] ITC: International Trade Centre [online]. Available: http://www.intracen.org/.

[2] MCKINNON, A. C.: Benchmarking Road Freight Transport: Review of a Government-Sponsored Programme. Benchmarking: An International Journal, 16(5), 640-656, 2009. https://doi.org/10.1108/14635770910987850

[3] GUNASeKaran, A., PATEl, C., TiRTiRoglU, E.: Performance Measures and Metrics in a Supply Chain Environment. International Journal of Operations \& Production Management, 21(1/2), 71-87, 2001. https://doi.org/10.1108/01443570110358468

[4] CAPLICE, C., SHEFFI, Y.: A Review and Evaluation of Logistics Metrics. The International Journal of Logistics Management, 5(2), 11-28, 1994.

[5] Council of Logistics Management [online]. Available: https://cscmp.org/ [accessed 2018-04-02].

[6] STOPKA, O., CERNA, L., ZITRICKY, V.P.: Methodology for Measuring the Customer Satisfaction with the Logistics Services. Nase More/Our Sea, 63(3), 189-194, 2016. https://doi.org/10.17818/NM/2016/S121

[7] KUBASAKOVA, I., KAMPF, R., STOPKA, O: Logistics Information and Communication Technology. Communications Scientific Letters of the University of Zilina, 16(2), 9-13, 2014.

[8] KRAJCOVIC, M., STEFANIK, A., DUlinA, L.: Logistics Processes and Systems Design Using Computer Simulation. Communications - Scientific Letters of the University of Zilina, 18(1A), 87-94, 2016.

[9] GNAP, J., KONECNY, V., VARJAN, P.: Research on Relationship between Freight Transport Performance and GDP in Slovakia and EU Countries. Nase More/Our Sea, 65(1), 32-39, 2018. https://doi.org/10.17818/NM/2018/1.5

[10] JAVALGI, R., MARTIN, C.: Internationalization of Services: Identifying the Building-Blocks for Future Research. Journal of Services Marketing, 21(6), 391-397, 2007. https://doi.org/10.1108/08876040710818886

[11] SAEZ, S., TAGLIONI, D., VAN DER MAREL, E., ZAVACKA, V.: Valuing Services in Trade: A Toolkit for Competitiveness Diagnostics. The World Bank, Washington DC, 2014.

[12] WINSTED, K. F., PATTERSON, P.: Internationalization of Services: The Service Exporting Decision. Journal of Services Marketing, 12(4), 294-311, 1998.

[13] STERNAD, M., JUSTINEK, G., CVAHTE OJSTERSEK, T.: International Comparison of Import and Export Efficiency of Transport Services. International Journal of Diplomacy and Economy, 3(1), 75-84, 2016. https://doi.org/10.1504/ IJDIPE.2016.079167

[14] HILMOLA, O. P.: European Railway Freight Transportation and Adaptation to Demand Decline: Efficiency and Partial Productivity Analysis from the Period of 1980-2003'. International Journal of Productivity and Performance Management, 56(3), 205-225, 2007. https://doi.org/10.1108/17410400710731428

[15] PETROVIC, M., PEJCIC-TARLE, S., VUJICIC, M., BOJKOVIC, N.: A DEA Based Approach for Cross-Country Evaluation of Rail Freight Transport. Proceedings of the conference Building a Smarter Future, Bulgaria, 152-156, 2012.

[16] MARTI, L., MARTIN, J.C., PUERTAS, R.: A DEA-Logistics Performance Index. Journal of Applied Economics, 20(1), 169-192, 2017. https://doi.org/10.1016/S1514-0326(17)30008-9

[17] World Bank [online]. Available: https://lpi.worldbank.org/.

[18] CHARnES, A., COOPER, W., LEWIN, A. Y., SEIFORD, L. M.: Data Envelopment Analysis: Theory, Methodology and Applications. Springer Science+Business, New York, 1994.

[19] VIRTOS, H.: Open Source DEA [online]. Available: http://opensourcedea.org/.

[20] ARVIS, J. F., SASLAVSKY, D., OJALA, L., SHEPHERD, B., BUSCH, C., RAJ, A., NAULA, T.: Connecting to Compete 2016: Trade Logistics in the Global Economy [online]. World Bank, 2016. Available: https://wb-lpi-media.s3.amazonaws.com/ LPI_Report_2016.pdf.

[21] CERNA, L., MASEK, J.: The Proposal the Methodology of the Supply Chain Management in Transport and Logistic Company. Proceedings of the International Scientific Conference Transport Means, Lithuania, 567-570, 2015.

[22] European Commission: Fact-Finding Studies in Support of the Development of an EU Strategy for Freight Transport Logistics: Analysis of the EU Logistics Sector, 2015. 